\title{
Autonomy in language learning: a case study with Italian as a second language
}

\author{
Maria Vittoria Lo Presti
}

Università Cattolica del Sacro Cuore, Milan, Italy.

\footnotetext{
Abstract

The aim of this paper is to investigate the development of autonomy in learning Italian as a second language (L2).

The analysis is based on the experience of the language advisor of the "Centro per l'Autoapprendimento" (CAP) of the Università Cattolica del Sacro Cuore (Milan) with sixteen foreign students.

In the introduction, the usefulness of university self-access centres (SAC) is briefly introduced, and the CAP is presented. The second part of the article concerns one of the case studies on sixteen foreign university students who participated in a didactic project on the development of the oral production skill that introduced them to the CAP, the language advisor, and the concept of autonomy in learning Italian.

The project ended with a final self-assessment questionnaire that allowed the learners to understand their strengths and weaknesses, and enabled the language advisor to verify the effectiveness of the activity.

Keywords: Autonomy in language learning; Italian as a second language; language advising.
} 


\section{Introduction}

Autonomy in language learning is a widely studied concept and today represents one of the most discussed topics regarding new teaching methodologies (Benson, 2006). There is a growing trend that aims to promote the development of autonomy in school and university language courses (Hobbs \& Dofs, 2017); this trend is evident from the fact that the learning to learn competence is one of the eight key competences of the European Reference Framework of Key Competences for Lifelong Learning1. Consequently, many universities, in Italy and abroad have already set up self-access centres (SAC) to promote autonomy in language study programmes2, and others are in the process of doing so (Choi, 2017). In the SACs, not only students can learn the most appropriate strategies to acquire or improve their language skills, but they can also take advantage of support activities for language courses, which consider the needs, rhythms and times of each student. It could be said that SACs have the function of integrating language learning with autonomous learning, allowing those who use them to improve both language and autonomy skills, providing adequate resources and ensuring the necessary support for learning (Reinders \& Lázaro, 2007).

In the Italian context, among the potential users of university SACs there is a growing number of international students, to whom the attention of this paper is directed. As is common knowledge, there are more and more students involved in international mobility programmes, for example foreign students enrolled in undergraduate and master's degree courses or doctoral schools, or foreign students enrolled in double degree courses or participants in projects such as Marco Polo or Erasmus. This article deals with a case study carried out at the SAC of the Università Cattolica del Sacro Cuore (Milan), the Centro per l'Autoapprendimento (CAP), which involved sixteen foreign students.

The premise from which to start is that the development of autonomy in learning is useful for the growth of the person and for the development of multilingual competence, and this presupposes a high degree of maturity, awareness and responsibility in students-qualities that the University has to promote as an educational institution.

In this article, which is actually part of a broader study, a didactic project is described which involved an introductory path for the development of autonomy in learning Italian. In particular, the above-mentioned sixteen foreign students were offered an activity consisting of a cycle of meetings with the language advisor of Italian for foreigners of the CAP, aimed at preparing an oral presentation in Italian on a topic inherent to their specific academic

\footnotetext{
${ }^{1}$ For more information about the Eight Competences visit: https://eur-lex.europa.eu/legalcontent/EN/TXT/?uri=uriserv:OJ.C_.2018.189.01.0001.01.ENG\&toc=OJ:C:2018:189:TOC (Last accessed: 21/02/2021).

${ }^{2}$ For further information and ongoing projects about university SACs visit: ALMS - Autonomous Language Learning Modules at the University of Helsinki (Last accessed: 11/05/2021).
} 
training. With this activity, the advisor aimed to introduce international learners to the CAP and encourage autonomous learning and, at the same time, to promote the development of their oral production skills in Italian. The activity proposed to non-Italian-speaking learners is commented on through the analysis of the data collected through self-assessment questionnaires.

The final reflection includes a comment on the effectiveness of the project carried out, the effective role that the CAP has for international users, the results produced by the activities conceived by the language advisor and how it can still be improved in order to propose good practices useful for the development of autonomy in learning Italian as L2 in a university context.

\section{Methodology}

The methodology used in this research paper is the case study. In fact, it started with the observation of international learners of Italian L2 at the CAP, during the first semester of the academic year 2018/19, with the collection of data through questionnaires. In total, sixteen learners were involved, none of whom had any previous experience in the field of autonomy in language learning, and the language used was exclusively Italian. These were students attending two master's degree courses (Master in International Marketing Management and Master in Luxury goods Management) with extremely heterogeneous levels of knowledge of the Italian language (from A1 to B2 of the Common European Framework of Reference for Languages - CEFR). The master's degree courses are taught exclusively in English and, consequently, international students never have the opportunity to interact in Italian during the lessons. The only opportunity these students have to practice the Italian language at the University is provided by the Italian course ${ }^{3}$.

The objective of this study was therefore on the one hand to promote the development of autonomy in learning Italian L2 by encouraging the students to attend the CAP, stimulating them to linguistic and metacognitive reflection, and on the other hand to help the students to be able to express themselves in Italian without fear of being judged.

We tried to find answers to the following questions:

1. How can international students approach the development of autonomy in language learning?

2. Can a path that provides the gradual approach of students to language advising be effective?

\footnotetext{
${ }^{3}$ All the students attended an Italian course with a teacher who proved to be very willing to contribute to the success of the didactic project described in this article.
} 
3. What are the major difficulties that an international learner can identify in exercising his oral skills?

In order to try to answer these questions, the language advisor organized some meetings at the CAP in which, with her support, the learners participated and prepared an oral presentation in Italian to be presented to their classmates and the Italian teacher at the end of the learning stage.

We used one tool to evaluate the work done. It was a self-assessment form prepared by the language advisor so that the students' opinions about their presentations would be as objective as possible. It was decided to record the students' presentations and thus give them the opportunity to listen to themselves again and to self-evaluate: the purpose was to enable the students to reflect on their mistakes in order to stimulate the critical spirit and awareness of the level of preparation achieved, consequently encouraging also the development of autonomy. Needless to say, the self-assessment phase is absolutely essential for the ultimate pedagogical purpose that is autonomy in learning. The self-assessment form contained eleven sentences (for example: I presented exactly the contents I had prepared; The grammatical structures were correct; The vocabulary was rich and appropriate; I am satisfied with my explanation in all respects) to be evaluated on a scale that went from "not at all" to "a lot". It also allowed a reflection on the activity (Did I like the activity? What kind of criticalities did I encounter?), on the language learning path (Was the activity useful for learning the Italian language? In which aspects of the language have I improved? And in which aspects would I still like to improve?) and on the relationship with the language advisor (Do I consider the activity carried out with the language advisor useful?). The questionnaires were useful tools for evaluating the work carried out, and thanks to them it was possible to identify the strengths of the didactic project, define the task of the language advisor and highlight the critical issues and the greatest and most frequent difficulties encountered by the users, and suggest some ways to resolve them.

\section{Data collection and analysis}

The topics chosen by the students for the Italian presentations varied according to the fields of study and the level of knowledge of the language. Clearly, for students whose level was very low (A1-A2 of the CEFR), an easy topic was chosen, in agreement with the language advisor.

A very important aspect is that the activity was optional, not mandatory. Having established the themes and dates of the language advice sessions at the CAP, we specified that these were not mandatory either.

During the first session, the CAP was presented with its materials and digital resources; the didactic project was explained again, and examples of sources considered "authoritative" and 
valid to be used for research at university level were shown. In addition to the presentation of the sources, a reflection was started on the linguistic weaknesses of each learner. From the first session, all the students managed to prepare a presentation schedule, despite the difficulties ("it is difficult, but it is useful")-which were certainly due to the fact that they were not used to speaking in Italian. Some students found the activity "moderately difficult", some for the terminology, others for the oral interaction: "Medium difficulty. The complexity is finding the right words in Italian".

As we have already mentioned, the didactic project was designed precisely to stimulate learners not only to use the CAP materials and to discover the development of autonomy in learning, but also to allow students to practice their oral skills. The fact that many had reported great difficulty in expressing themselves in Italian (at least initially) led the advisor to reflect and, above all, prompted further dialogue with the students and among the students themselves to help them find solutions.

During the following advising session, the learners searched for videos in Italian on the chosen topic, to give them greater confidence with the subject and to learn new terms in Italian. Finally, during the last session, the students were asked to work in pairs to repeat their own presentations and listen to those of their classmates with the aim of developing both comprehension and speaking skills. The comparison activity between students seems to have been useful:

"It was difficult, but it is a useful activity because I learned lot of Italian words and I met new people".

"It is a bit difficult, but I found the whole project very useful. There are many useful materials for my study. It was useful to talk about the project with Emma because now I am less afraid of making mistakes".

The goal was to reassure students about the work done and to encourage them with regard to the presentation. On the day of the presentation, only 13 out of 16 students wanted to present their work to the class, although all of them had attended the advising sessions at the CAP. The presentations were recorded, and the students were asked to listen to themselves so that they could assess their own presentations.

Table 1 shows the data relating to student self-assessments. The main problem is related to nervousness: only $14 \%$ of the students felt "quite" or "very" relaxed during the presentation. Another issue to be noted concerns the correctness of grammatical structures: only $15 \%$ of students declared they were "very" satisfied after listening to their own recording. 
Table 1. Students' self-assessments

\begin{tabular}{|c|c|c|c|c|c|}
\hline & $\begin{array}{c}\text { NO } \\
\text { ANSWER }\end{array}$ & $\begin{array}{c}\text { NOT } \\
\text { AT ALL }\end{array}$ & $\begin{array}{c}\text { A } \\
\text { LITTLE }\end{array}$ & QUITE & VERY \\
\hline $\begin{array}{l}\text { I presented exactly the contents I had } \\
\text { prepared }\end{array}$ & $0 \%$ & $7 \%$ & $15 \%$ & $53 \%$ & $23 \%$ \\
\hline $\begin{array}{l}\text { I remembered everything I wanted to } \\
\text { say }\end{array}$ & $0 \%$ & $7 \%$ & $38 \%$ & $38 \%$ & $15 \%$ \\
\hline I was relaxed & $0 \%$ & $38 \%$ & $46 \%$ & $7 \%$ & $7 \%$ \\
\hline $\begin{array}{l}\text { My posture was correct for a } \\
\text { presentation of this type }\end{array}$ & $7 \%$ & $0 \%$ & $7 \%$ & $69 \%$ & $15 \%$ \\
\hline $\begin{array}{l}\text { My explanation was developed with a } \\
\text { logical and coherent sequence }\end{array}$ & $0 \%$ & $0 \%$ & $15 \%$ & $31 \%$ & $53 \%$ \\
\hline I expressed the concepts clearly & $0 \%$ & $7 \%$ & $31 \%$ & $46 \%$ & $15 \%$ \\
\hline The grammatical structures were correct & $0 \%$ & $15 \%$ & $46 \%$ & $23 \%$ & $15 \%$ \\
\hline My pronunciation was good & $7 \%$ & $0 \%$ & $46 \%$ & $38 \%$ & $15 \%$ \\
\hline The lexicon was rich and appropriate & $0 \%$ & $15 \%$ & $23 \%$ & $53 \%$ & $7 \%$ \\
\hline $\begin{array}{l}\text { My voice was calm and the volume was } \\
\text { adequate }\end{array}$ & $0 \%$ & $7 \%$ & $15 \%$ & $53 \%$ & $23 \%$ \\
\hline $\begin{array}{l}\text { I am satisfied with my account in all } \\
\text { respects }\end{array}$ & $7 \%$ & $7 \%$ & $23 \%$ & $61 \%$ & $0 \%$ \\
\hline
\end{tabular}

Table 1 demonstrates that the future work of the language advisor should aim to make students feel comfortable and confident in their abilities both at the CAP and in the classroom. Despite the difficulties due to the impact with the audience, formed by classmates and the teacher, the activity was appreciated by all students, in particular the opportunities to "learn something new from the presentations of classmates" and "learn to overcome the fear of speaking Italian in front of other people". One student admitted that she had worked on "emotion control" and had learned how to manage her emotions for presentation. Another student appreciated the work of the language advisor at the CAP as "we found the best teaching approach for the group". The main difficulty was remembering the new terms they had learned and concentrating on the grammatical structures while speaking; one student highlighted the "transition from written text to oral text" among the difficulties; however, those difficulties were the aspects of the language in which all students felt they had improved thanks to the project. 
The contribution of the language advisor to the activity was defined as useful for helping in the organization of the presentation, correcting grammatical errors and finding suitable sources. Two students reported that the activity was not profitable for the purpose of learning Italian and three did not consider the activity with the language advisor to have been useful. Among the aspects of the language to be improved, oral skills are still significant, followed by "grammar (verbs and connectives)", "vocabulary" and "sentence structure".

Overall, the project proved to be effective both for learning Italian and for introducing the functions of the CAP and discovering the figure of the language advisor. The students who had identified weaknesses in oral production during the first session at the CAP havethrough practice-learned to overcome their fear of presenting in Italian, thanks to this language advising activity.

\section{Conclusion}

This article aimed to demonstrate how a group of international students could be helped to be more autonomous learners of Italian L2 through a didactic project, the purpose of which was the development of oral skills through the discovery of the figure of the language advisor, the CAP and its materials.

Reflecting on the real effectiveness of the advising sessions, it appears that, during the meetings at the CAP, numerous learning strategies were developed through talking to the advisor and peers regarding the search for sources, the passage from written to oral text and the organization of the speech. The project therefore brought various benefits to the learners: firstly, by improving lexical and specialist vocabulary skills in L2 and developing oral skills, and secondly, it encouraged students to reflect on their knowledge of Italian and on what they would still like to improve, trying to find the tools suited to their needs, independently or with the help of the language advisor. At the CAP, the learners felt free to express their concerns without fear of being judged. Working with the language advisor, the students learned to ask questions, seize opportunities to clarify doubts, practice the language, manage their time more effectively and consult resources they did not know existed. Thanks to the self-assessment questionnaires, the need to investigate aspects of the language emerged which, in some cases, were subsequently taken up in the classroom by the Italian teacher.

Clearly, also critical issues emerged from such a project. The greatest was undoubtedly the difficulty encountered by learners with level A1-A2 of the CEFR; for these students, such an activity turned out to be very difficult. With regard to any further projects, it would be advisable not only to simplify the topics chosen for the presentation, but also to organize advising sessions and didactic activities exclusively for these students. That said, the greatest difficulty for all levels was practising the ability to speak, as seen from the analysis of the questionnaires; however, despite this difficulty, the activities of the project were appreciated 
as, albeit not mandatory, all students participated in the meetings organized at the CAP and $81 \%$ presented the work to the rest of the class and to the Italian L2 teacher.

New proposals could be made to improve the language learning advising service at the university; for example, preliminary advising sessions could be organised to introduce the theme of the development of autonomy: raising awareness among students about the importance of becoming autonomous learners could be the first step towards more effective and lifelong learning.

A final consideration concerns the moment of uncertainty and change that we are experiencing; it will certainly be necessary to continue the research in the field of autonomy, in the light of the new educational needs, such as rethinking ways to make language advising effective for online learning.

\section{References}

Benson, P. (2006). Autonomy in language teaching and learning. Lang. Teach., 40, 21-40. Cambridge: University Press. doi:10.1017/S0261444806003958

Choi, J. (2017). The metamorphosis of a self-access centre in Hong Kong: From theory to practice (a case study). Studies in Self-Access Learning Journal, 8(1), 23-33. doi:10.37237/080103

Gardner, D., \& Miller, L. (2014). Managing self-access language learning. Hong Kong: City University of Hong Kong Press.

Hobbs M., \& Dofs, K. (2017). Self-access centre and autonomous learning management: where are we now and where are we going?. Studies in Self-Access Learning Journal, 8(2), 88-101. doi:10.37237/080203

Holec, H. (1981). Autonomy in Foreign Language Learning. Oxford: Pergamon.

Little, D. (1991). Learner Autonomy. 1: Definitions, Issues and Problems. Dublin: Authentik.

Reinders, H., Lázaro, N. (2007). Innovation in self-access: Three case studies. CALL-EJ, 8,(2), 1-14. Retrieved from: http://callej.org/journal/8-2/lazaro_reinders.html

Zanola, M.T. (2012). L'autonomia nella formazione linguistica universitaria: il ruolo del Centro per l'Autoapprendimento dell'Università Cattolica. Quaderni del SeLdA, 1. Milano: Educatt. 